"Technological orders' change caused by the pandemics: Digitalization in the internationalization of technology transfer"

\begin{tabular}{|c|c|}
\hline AUTHORS & $\begin{array}{l}\text { Kateryna Alekseieva (iD) } \\
\mathbb{R} \\
\text { Iryna Novikova (D) } \\
\mathbb{R} \\
\text { Oleksandr Bediukh (D) } \\
\text { Olga Kostyuk (D) } \\
\mathbb{R} \\
\text { Alla Stepanova (D) } \\
\mathbb{R}\end{array}$ \\
\hline ARTICLE INFO & $\begin{array}{l}\text { Kateryna Alekseieva, Iryna Novikova, Oleksandr Bediukh, Olga Kostyuk and Alla } \\
\text { Stepanova (2021). Technological orders' change caused by the pandemics: } \\
\text { Digitalization in the internationalization of technology transfer. Problems and } \\
\text { Perspectives in Management, 19(3), 261-275. doi:10.21511/ppm.19(3).2021.22 }\end{array}$ \\
\hline DOI & http://dx.doi.org/10.21511/ppm.19(3).2021.22 \\
\hline RELEASED ON & Friday, 10 September 2021 \\
\hline RECEIVED ON & Saturday, 08 May 2021 \\
\hline ACCEPTED ON & Thursday, 22 July 2021 \\
\hline LICENSE & $\begin{array}{l}(0) \text { EY } \\
\text { This work is licensed under a Creative Commons Attribution } 4.0 \text { International } \\
\text { License }\end{array}$ \\
\hline JOURNAL & "Problems and Perspectives in Management" \\
\hline ISSN PRINT & $1727-7051$ \\
\hline ISSN ONLINE & $1810-5467$ \\
\hline PUBLISHER & LLC "Consulting Publishing Company "Business Perspectives" \\
\hline FOUNDER & LLC "Consulting Publishing Company "Business Perspectives" \\
\hline
\end{tabular}

NUMBER OF REFERENCES

27
NUMBER OF FIGURES

10
E=-

NUMBER OF TABLES

0

(C) The author(s) 2021. This publication is an open access article. 


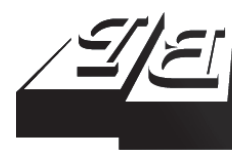

BUSINESS PERSPECTIVES

O

LLC "CPC "Business Perspectives" Hryhorii Skovoroda lane, 10, Sumy, 40022, Ukraine www.businessperspectives.org

Received on: $8^{\text {th }}$ of May, 2021 Accepted on: 22 $2^{\text {nd }}$ of July, 2021 Published on: $10^{\text {th }}$ of September, 2021

(c) Kateryna Alekseieva, Iryna Novikova Oleksandr Bediukh, Olga Kostyuk, Alla Stepanova, 2021

Kateryna Alekseieva, Ph.D., Assistant Professor, Faculty of Agrarian Management, Department of Production and Investment Management, National University of Life and Environmental Sciences of Ukraine, Ukraine. (Corresponding author)

Iryna Novikova, Doctor of Economics, Senior Researcher, Taras Shevchenko National University of Kyiv, Ukraine.

Oleksandr Bediukh, Ph.D., Senior Researcher, Taras Shevchenko National University of Kyiv, Ukraine.

Olga Kostyuk, Ph.D., Assistant Professor, Faculty of Agrarian Management, Department of Administrative Management and Foreign Economic Activities, Nationa University of Life and Environmental Sciences of Ukraine, Ukraine.

Alla Stepanova, Ph.D., Assistant Professor, Faculty of Economics, Department of Management of Innovative and Investment Activity, Taras Shevchenko National University of Kyiv, Ukraine.

This is an Open Access article, distributed under the terms of the Creative Commons Attribution 4.0 International license, which permits unrestricted re-use, distribution, and reproduction in any medium, provided the original work is properly cited.

Conflict of interest statement Author(s) reported no conflict of interest
Kateryna Alekseieva (Ukraine), Iryna Novikova (Ukraine), Oleksandr Bediukh (Ukraine), Olga Kostyuk (Ukraine), Alla Stepanova (Ukraine)

\section{TECHNOLOGICAL ORDERS' CHANGE CAUSED BY THE PANDEMICS: DIGITALIZATION IN THE INTERNATIONALIZATION OF TECHNOLOGY TRANSFER}

\begin{abstract}
The COVID-19 pandemic has become a catalyst for changing the technological order of human development and has accelerated the formation of new forms of organization and business. The change of technological orders causes uneven development of scientific and technological progress, as a result of which the existing technologies deepen, which become dominant and can be superimposed on the existing technological way of life. The purpose of the study is to substantiate changes in technology orders and to analyze the process of digitization as a new trend in the internationalization of technology transfer based on data on the dynamics of business meetings at brokerage events recorded in the Enterprise Europe Network (EEN). The use of EEN IT platform tools and general scientific methods such as analysis and synthesis, induction and deduction, and historical analysis has confirmed the differences between the fifth and sixth technological orders and demonstrated the search for new ways of development for small businesses. The study formulated a general strategy for the digitization process and recommendations for the internationalization of technology transfer using Enterprise Europe Network tools in a pandemic, which include intensifying business activities using cyberspace, changing existing forms of organization, and innovation for small businesses. This strategy became the basis for the formation of a new methodological paradigm for managing the process of internationalization of technology transfer, taking into account the peculiarities of the domestic economy in a pandemic.
\end{abstract}

\section{Keywords}

innovation, digitalization, internationalization, orders, pandemics, technologies, EEN

JEL Classification F02, F62, O31, O32, Q55

\section{INTRODUCTION}

In current conditions, the world economy has faced a new unprecedented challenge caused by the spread of the pandemic of coronavirus around the world. The crisis has touched the developed countries and required deep and crucial changes in the structure of the economy of the world towards accelerating its digitalization due to the need for new forms of organization of work and business, i.e., distant forms. It should be admitted that in the essence such changes can be understood as the vivid appearance of the change of the technological orders worldwide when the change in the production relations leads to the changes in the productive forces and vice versa. Such crucial changes in technologies are used to happen before, for example, they were pushed by the wars. In current conditions, the social and economic system of the world is definitely ready for the change of technological orders and the pandemic became the factor to accelerate this process. Since Negroponte (1995) determined the process of digitalization for the first time, it became a trend and touched all the spheres of the economy. However, the worldwide pandemic rushed digitaliza- 
tion. Taleb (2007) wrote about some key factors to hurry the changes and the pandemic can be considered such a factor.

Therefore, the task is to study the impact of digitalization on various areas of the economy and changes in people's lives and business activities. In this connection, the opportunities debugging for international cooperation to facilitate cross-border technology transfer and business partnerships based on specialized network platforms such as Enterprise Europe Network (EEN) are explored. The forms of cooperation in technology transfer change towards virtualization because of the pandemic. The pandemic caused the intensification of digitalization processes in the economy and all the events, in particular, the EEN events obtain new virtual forms.

Based on the facts determined above the present study focuses on consideration of the change of technological orders that was forced by the pandemic. The vivid appearance of this change is the process of digitalization that touched all the spheres of the economy and led to shifting the forms and ways of running business toward the online ones.

The importance and relevance of the task to study the change of technological orders in conditions of digitalization and observing some visual examples of the process in particular studying of the EEN data can significantly raise the conceptual understanding of the overall changes in the world economy today. The results of the study can be used as a source of information concerning changing of technological orders in conditions of the pandemic spread.

\section{LITERATURE REVIEW AND HYPOTHESES DEVELOPMENT}

The problems of digitalization of economy have been discussed within last years by theorists, politicians and public persons whereas the change of technological orders issue has become a topic number one among the scientists only now. Certainly, coming crucial changes are used to be discussed and published in the scientific literature. For instance, Taleb's work (2007) can be considered vivid evidence of waiting for some crucial factor to push the changes of technological orders that the pandemic of the coronavirus became.

As for digitalization as one of the appearances of the changes in the technologies, Negroponte (1995) was the first to use the word "digitalization" and to define it in the works. Various features of the general process of digitalization were determined. According to the data published by the news resource "EDIN", the process of digitalization became a worldwide trend. In 2019 in Ukraine, the word "digitalization" was determined as the most used word in online content. Radu (2018) indicated the top industries to be changed by automation.
Many Ukrainian scientists have been doing their best to research the process of digitalization in the domestic economy. Lazebnyk (2018) studied the digitalization of economic relations as a factor in improving business processes. Some interesting analytics concerning the coronavirus and the economic crisis in the world can be found in economic and political reviews (Yang et al., 2019).

In this regard, the analysis of the activities of specialized international information and communication network forms of technology transfer, and especially the EEN, which activities are aimed at the internationalization of innovative business, knowledge, and technology. Bertosh (2010), Jakubiak and Chrapowicki (2017), Fry (1982), and Meshko and Robota (2008) made a significant contribution to the development of this issue. Thus, Jakubiak and Chrapowicki (2017) considered EEN as an institution that promotes the internationalization of small and medium science-intensive enterprises. Bertosh (2010) focused on the problem of forming a modern mechanism of international information technology transfer, the main subjects of which are transnational corporations, innovative firms, engineering companies, outsourcing companies, as well as scientific and public organizations that form multilateral inter-firm 
flows. Stepanova et al. (2019) briefly focused on the contradictions of the use of the European network of enterprises in Ukraine, as well as offered strategic solutions for the successful use of EEN tools by the Ukrainian enterprises and organizations. Transnational organizations that have acted as international technology transfer centers have played and continue to play the role of "technology mentors" in the development of high-tech industries in Korea and other Asian countries (Cyhn, 2002). Jakubiak and Chrapowicki (2017) focused on international technology transfer and emphasized public attention to technology transfer between universities as a new phenomenon, which with a balanced strategic approach contributes to the socio-economic development of individual regions and countries in general (China, Europe, and the USA). In modern processes of internationalization of technology transfer, scientists, entrepreneurs, and government officials constantly face the problem of information hunger, imperfection of innovation markets due to which the adoption of already complex decisions that shape the choice of strategic vectors for the selection and use of new technologies becomes even more difficult, according to Derakhshani (1984). In modern research, Kotlyarevsky et al. (2020) rightly argued that the era of scientific and technological revolution has qualitatively changed the content and balance of the processes of integration and differentiation of science. Among the integration trends in the development of economic research, the active impulses of scientific heuristics, which form perspectives and guidelines for the evolution of forms and methods of cognition, have had a noticeable influence. One of such phenomena is the formation of a new paradigm of economics (from the economy of the information sphere to the digital economy) as a special type of theoretical and applied research. In recent years, in the scientific research environment, there have been active processes of conceptualization of the phenomenon of neoeconomics and its structural elements. Araújo and Teixeira (2013) proved that the emergence of a knowledge-based economy creates the imposition of anticipations, which lead to the institutional restructuring of intellectual potential, where one of the key factors determining the effectiveness of international technology transfer are highly professional human resources.
In search of the dynamic intelligent growth of the technology transfer, Carayannis et al. (2020) actively continued to consider new theories that will influence the formation of new political and practical trajectories of innovative development. In particular, to expand the focus of innovative entrepreneurship, Kruger and Steyn (2020) recommended conducting more research based on the use of institutional theory, when innovation platforms are used as a launching pad to increase their success. Agostini et al. (2020) proved that the dynamics of generation and transfer of technology are growing in terms of merging and combining human and geographical dimensions. However, some countries, such as China, often use a coercive technology transfer arrangement that allows their domestic companies to access foreign technology if investors invest in the country (Sykes, 2021). Methodological approaches to the management of innovation and technological risks in a market economy are described by Smith and Parr (2005), etc.

Despite the value of the studies that have already been carried out by scholars, there are some important methodological aspects of the change of technological orders pushed by the pandemic threat left without attention.

The tasks of the paper are to:

- determine the "technological order" as a scientific term and distinguish the fifth and sixth technological orders from each other;

- determine the pandemics of the coronavirus as a factor of accelerating the change of the technological orders;

- describe the main features of the production relations and productive forces, which are forming in the new conditions and start dictating the new forms of organization and business doing, i.e. the distant ones;

- show the digitalization of all spheres and branches of economy as a vivid appearance and trend of the new technological order;

create visual schemes describing the mentioned processes in the world economy; and 
- illustrate the gradual change of technological structures in the information and communication sphere via the presentation of the data about the events of EEN in 2020 in comparison to 2019, as well as show the influence of the pandemic on it.

Thus, based on the literature review, the following hypotheses have been established:

H1. The change of technological orders has been caused by the spread of the pandemic of the coronavirus.

H2. In the new conditions, the digitalization of all spheres of the economy has become the main trend changing the essence of production relations among people.

H3. The new forms of business running (the distant ones) have been quickly developed and events aimed at internationalization of technology transfer are organized distantly.

\subsection{Substantiation of $\mathrm{H} 1$}

Recently the world has faced a new challenge that has accelerated the changes of the technologies in all branches of the world economy having put the digital, in particular distant technologies, to the primer positions. This challenge was the appearance and worldwide spread of a new unknown before the COVID-19 that caused a pandemic.

The phenomena of epidemics and pandemics have been known to humankind for a long time. An epidemic is the incidence of an infection when the degree of its spread exceeds that usually recorded in the same period in the area (Yang et al., 2019). A pandemic (from the Greek 'pan' - all, and 'demos' - the people) is an epidemic characterized by the spread of infectious diseases throughout the country, neighboring countries, and in some cases many countries (e.g. cholera, plague, AIDS, and flu). In the past, the pandemic spread of infectious diseases such as plague, cholera, smallpox, and typhus have been devastating: they used to claim 50 to 100 million lives worldwide. In the early XX century, due to technological progress (trains, airships, and high-speed ships), a disease known as Spanish flu spread very quickly around the world.
The exact number of victims could not be definitively determined, but it was higher than the number of victims of World War I.

The coronavirus pandemic has caused the economic crisis of the world and has been followed by the change of technological orders. Tough quarantine measures have been carried out in many developed countries. There has been ceased air, and in some places, all communication among countries. Schools, universities, research centers, theaters, cinemas have been closed. Tournaments and championships have been discontinued. Even the Olympic Games were canceled. Such limitations are unprecedented, and so far, happened only during World War I and II. Of course, all these measures have become a challenge for the world economy having demanded quick changes in its structure.

It is necessary to admit that the world crisis has been something that should have happened, i.e., it has been expected by the scientists although the form of it was not easy to forecast (Radu, 2018). Not only could the biological viruses become a new threat but also information viruses, war conflicts, new inventions, etc., but some "black swan" was expected to appear (the "black swan" theory is a theory that examines difficult-to-predict and rare events that have significant consequences according to Taleb, 2007). Speaking of economic measures, three economic cycles were simultaneously reaching their end. The first one is overstocking at the warehouses of the largest companies (Kitchin cycle, 2-4 years). The second is connected with a reduction in global investment (Juglar cycle). The third is due to the transition to the sixth technological order: NBCI-convergence, where the main role will be played by nano- and biotechnologies, information, and cognitive factors (Kondratiev cycle).

\subsection{Substantiation of $\mathrm{H}_{2}$}

The process of digitalization obtains global features and becomes the main trend. In such conditions, the essence of the production relations among people changes drastically forming new digital ways of economic relations. It is well known that carrying out the process of production, people create certain connections not only 
with nature but also with each other. The characteristics of any mode of production are embedded into production relations, i.e. in the digital relations in current conditions. Production relations always reflect the development of the productive forces (people and existing digital technologies) and form the peculiarity of a particular social and economic system.

So that, the ongoing change of technological orders attributed to digitalization and accelerated by the pandemic emergency requires quick development of the whole system of the production relations in their connection with the productive forces (De Moortel \& Crispeels, 2018). Production relations are primarily relations among people in the process of production, distribution, exchange, and consumption of material goods, which exist in specific forms and types due to the quality of productive forces, as well as the form of ownership of the means of production. In the frames of the sixth technological order, the production relations are going to be formed distantly thanks to the spread of digitalization (Lee, 2020). The changes in production relations towards their digitalization begin with changes in the productive forces. However, production relations do not remain passive in this process influencing the development of productive forces (Block \& Hirschhorn, 1979).

\subsection{Substantiation of $\mathrm{H}_{3}$}

For business structures digitalization (in the frames of the sixth technological order) brings strengths and weaknesses, as well as opportunities and threats. The negative side for the executives is the lack of the possibility of long-term planning of different meetings, events, negotiations, as well as the high cost of attracting highly qualified specialists. The opportunities that digital technologies bring allow this drawback to be eliminated by developing online forms of business relations. Certainly, this is possible in case if the system of economic relations is ready for the changes, i.e., the productive forces and production relations can reach a new level (Cyhn, 2002). The absence of the need for the personal presence of participants of some events allows using distant forms of business doing and attracting specialists of a certain qualification. In this connection, the processes of organization, management, and control are sub- ject to change. From an organizational point of view, traditional forms of organization are being replaced by the "virtual" ones.

A vivid appearance of it is the change in the number of brokerage events of the EEN program. It is a program that helps small businesses to innovate and grow internationally in particular thanks to organizing different events aimed at creating a business partnership. The number of such events firstly decreased when the pandemic started but then grew again when the digital technologies (the distant ones) were implemented.

Thus, the current study aims to substantiate changes in technology orders and to analyze the process of digitization as a new trend in the internationalization of technology transfer based on data on the dynamics of business meetings at brokerage events recorded in the Enterprise Europe Network.

\section{RESULTS}

The progressive world, that is the developed countries of the world, has existed within the framework of the fifth technological order until the current period. Simply put, this means that a post-industrial information society based on the consumer services economy has been established as a social and economic model of well-doing countries of the world. The stated thesis requires an explanation of the category "technological order" that can be defined as a set of technologies and industries of a certain type, which are combined into stable self-reproducing integrity (Fry, 1982). It should be said that the change in technological orders that dominate the economy for some period determines the uneven movement of scientific and technological progress. Due to the emergence and formation of new technical specifications, depths of the previous one occur and, based on the existing production potential, stimulate further development. Then comes the restructuring of the economy based on new production technology and coincides with the dominance of a certain technological way of life. The new technological order establishes and brings the spread of the new technologies into the developed world. The rate of maturity of a particular technological order depends on favorable technological and socio-eco- 
The 5th technological order

\begin{tabular}{|c|c|c|c|c|}
\hline $\begin{array}{l}\text { General description } \\
\text { of the order } \\
\text { The main resource is } \\
\text { nuclear energy. The } \\
\text { main industries are } \\
\text { electronics and } \\
\text { microelectronics, } \\
\text { information } \\
\text { technology, genetic } \\
\text { engineering, software. } \\
\text { The key factor is } \\
\text { microelectronic } \\
\text { components. }\end{array}$ & $\begin{array}{l}\text { Forms of employment } \\
\text { Traditional } \\
\text { employment, full-time } \\
\text { work in the office or at } \\
\text { production, workplace } \\
\text { attachment, } \\
\text { communicational skills } \\
\text { of the workers are } \\
\text { crucial, team-building } \\
\text { is important. }\end{array}$ & $\begin{array}{l}\text { The main trend is } \\
\text { individualization of } \\
\text { production and } \\
\text { consumption } \\
\text { accompanied by rising } \\
\text { of sphere of services. } \\
\text { Globalization, } \\
\text { communication speed } \\
\text { and movement. }\end{array}$ & $\begin{array}{l}\text { Traditional } \\
\text { management system } \\
\text { at the enterprises is } \\
\text { aimed at fulfilment of } \\
\text { basic management } \\
\text { functions (planning, } \\
\text { organization, } \\
\text { motivation and } \\
\text { control) with } \\
\text { requirement to } \\
\text { provide the full-time } \\
\text { work of the employees } \\
\text { in the office. }\end{array}$ & $\begin{array}{l}\text { Existing of a traditional } \\
\text { consumer who waits } \\
\text { for market launch of a } \\
\text { new product, } \\
\text { appreciates the } \\
\text { opportunity to get } \\
\text { acquainted with the } \\
\text { goods "physically", is } \\
\text { limited in choice, often } \\
\text { makes spontaneous } \\
\text { purchases. }\end{array}$ \\
\hline
\end{tabular}

\section{The 6th technological order}

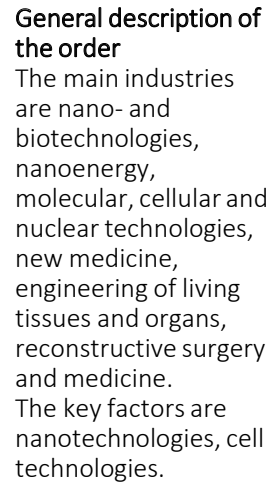

\begin{tabular}{l|l}
\begin{tabular}{l|l} 
Forms of employment \\
Digital technologies \\
change the forms of \\
employment towards
\end{tabular} & $\begin{array}{l}\text { The main trend is } \\
\text { digitalization of all } \\
\text { processes and spheres } \\
\text { distant ones: the }\end{array}$ \\
$\begin{array}{l}\text { of life including } \\
\text { proelance sphere, } \\
\text { outsourcing is actively } \\
\text { public services }\end{array}$ & $\begin{array}{l}\text { accompanied by } \\
\text { decrease in energy }\end{array}$ \\
is the possibility of \\
organizing remote and \\
project forms of \\
employment. A new \\
kind of team is being \\
consumption, lowering \\
of production costs \\
thanks to \\
team.
\end{tabular}$\quad \begin{aligned} & \text { virtualization. } \\
& \end{aligned}$

Transformation of management at the enterpises: changes in the processes of planning,organization, motivation and contro due to new distant forms of work, new approaches to timemanagement and control of the results.
Emergence of a new type of consumer who co-creates value, makes a choice more consciously (for instance, is aware of environmental dangerous), makes purchases over the Internet, has more choices.

Figure 1. Characteristics of the fifth and the sixth technological orders

nomic conditions of the environment. If there is a small but stable demand for new technology, process, product, the development of elements of the new technological order is accelerated. At some point, the dominating technologies exhaust themselves and the economy requires the change of the model. Certainly, the process of changing technological orders is always accompanied by a crisis of all spheres of human life. First, the level of structural unemployment becomes higher due to the structural changes in the economy and this can be the reason for social and even political conflicts, resistance to changes of people at all levels.

It should be said that the spread of the COVID-19 in the XXI century can be compared to the spread of the Spanish flu in the XX century. The peculiarity of the Spanish flu, which makes that disease related to the coronavirus, was that it did not spare well-doing countries with a developed system of medical care and, according to some reports, affected, first of all, well-off sections of the population, healthy, well-fed people with strong immunity. The coronavirus of the current century is not the only existing pandemic today but a pandemic that threatens the developed countries. According to the World Health Organization estimates, the epidemics of malaria (about 5 million dead) and AIDS (about 19 million dead) continue. However, these diseases mostly affect people outside the Golden Billion (population of the richest and most developed countries or well-doing families and re- 


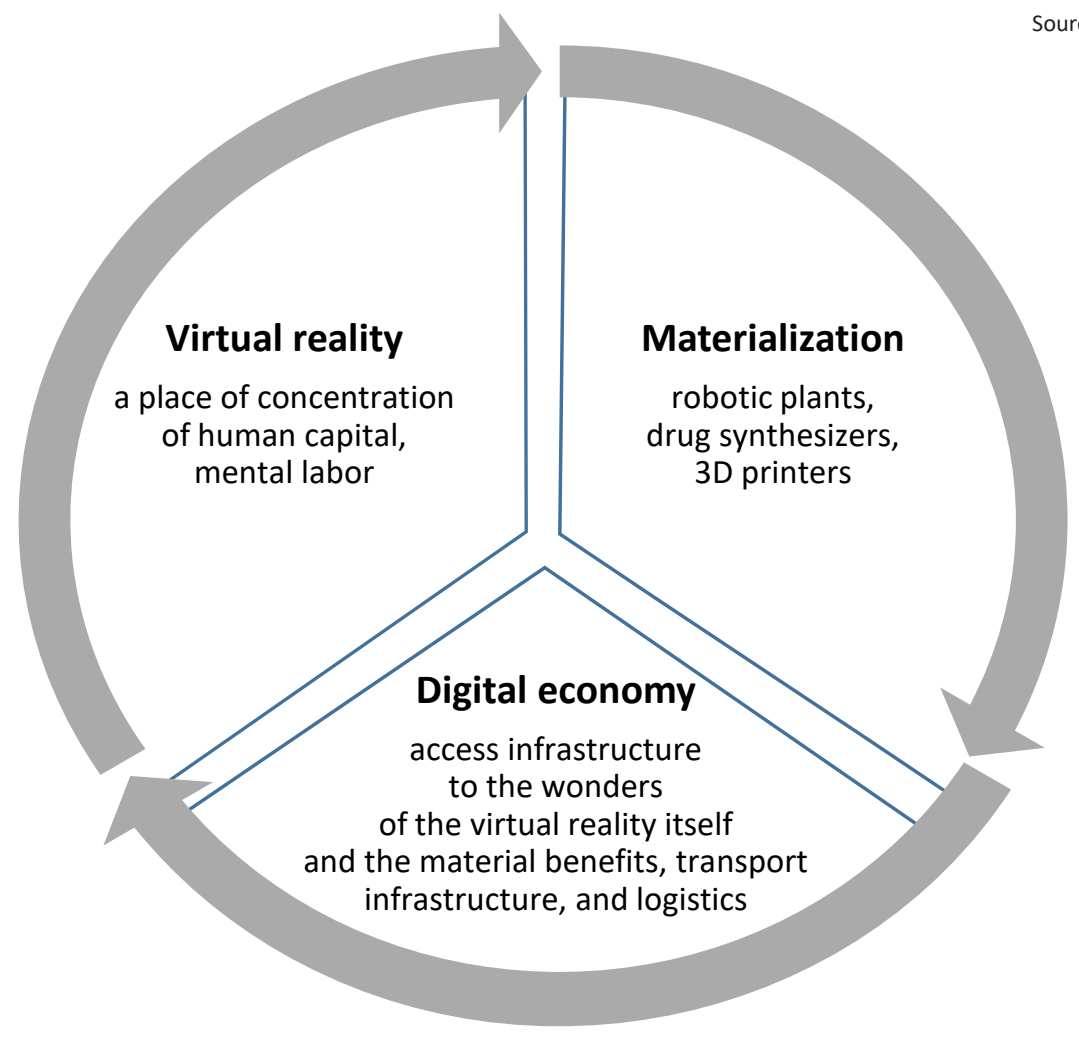

Figure 2. Forming sectors of the "new economy" inside the sixth technological order

flecting an imbalance in living standards and consumption between them and developing countries). Whereas the coronavirus has been actively attacking the USA and the prosperous European countries, the families of the so-called middle class, and even the richest people of the world (politicians and celebrities). In any case, the current pandemic will last 1-3 years and cause the illness from 75 to $90 \%$ of the population. A certain percentage of people will inevitably die from this disease (about $2.5 \%$ of all infected) (Melikyan, 2010).

As a result, the coronavirus became the factor to stimulate the changes in the world economy and the change of technological orders (Rachinger et al., 2019). The new technological order (the sixth technological order) will inevitably lead to the accelerating of the processes of digitalization of the economy (Figure 1).

Certainly, the digitalization itself can be understood as one of the vivid appearances (main trends) of the change of technological orders together with for instance transition from an internal combustion engine to more advanced engine models (electric, hydrogen) or searching for the ways of non-waste production, new medicine, new forms of or organization. As a matter of fact, digitalization will cause forming of a new branch of economy that will exist in the frames of the sixth technological order together with nanotechnologies, biotechnologies, new environmental consumption, etc. However, it is the digital sphere that is going to change the casual life of people and their mentality.

The digitalization that is actively going on will divide the economy into three sectors in the long run (Figure 2). The first is virtual reality, a place of concentration of human capital and mental labor. Here formulas, schemes, recipes, algorithms, projects, methods, and standards will be created (Araújo \& Teixeira, 2013). The second one is connected with the materialization of these schemes and recipes in reality. It involves robotic plants, drug synthesizers, 3D printers, etc. The third sector is what is called today the digital economy. This is an access infrastructure to the wonders of the virtual reality itself and the material benefits of the second material level of the new digital economy, transport infrastructure, and logistics. 

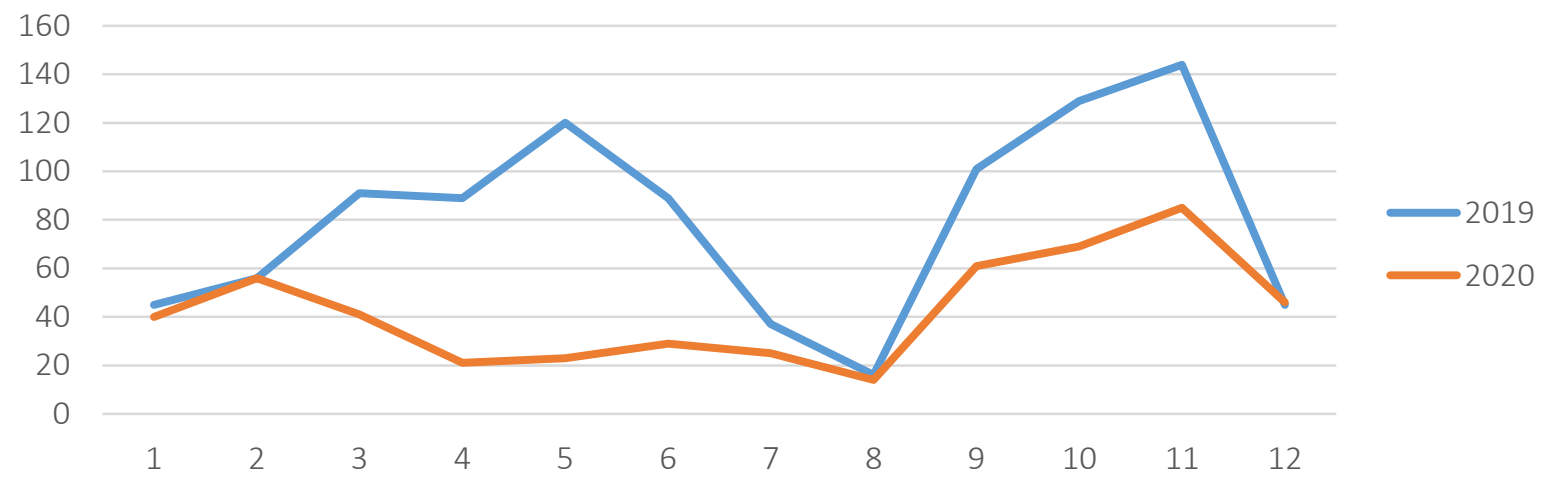

Figure 3. Distribution of the number of events by months in 2019 and 2020 according to the EEN event calendar

Everything that was created in the previous technological structure does not disappear in the next, remaining already non-dominant.

Destruction or reformation of the prosperous in the frames of the fifth technological order spheres of services and entertainment industry is also something that should be anticipated in the nearest future. The new distant forms of business doing in the conditions of quarantine limitations can be fatal for the mentioned spheres (Stepanova et al., 2019). Although as for the sphere of services some of them are to adapt (Kruger \& Steyn, 2020). For instance, the sphere of education can possess new features and become partly distant (kindergartens, elementary education, sports education should remain full-time whereas higher education can become partly distant).

Thus, the current pandemic has played the same role the wars used to play and lead to some revolutionary technological changes, i.e., wars have always been high-tech destructors of the economy. The world wars were marked by such global processes as changes of world leaders and technological orders. The same situation has happened now. The virus itself is real and dangerous but it would never become the reason for the crucial technological changes if the system were not ready to meet and accept those changes.

To illustrate the gradual change of technological structures in the information and communication sphere, data from the calendar of events of the Enterprise Europe Network in 2020 in comparison to 2019 were presented.
The EEN program helps small businesses to innovate and grow internationally. It is currently deployed in 70 countries around the world. It brings together over 3,000 experts and over 600 member organizations, including chambers of commerce and industry; technological platforms; innovation support organizations; universities and research institutes; regional development organizations. More than 3 million enterprises wishing to develop their business outside their country are now the EEN clients.

The EEN events calendar covers almost all major international events (brokerage events, company missions, conferences/seminars/information days, fairs/exhibitions, sector group meetings, training, working group meetings, workshops) in various areas of international business currently taking place in the world.

Figure 3 shows the distribution of events by month in 2019 and 2020 within the EEN events calendar.

One can see that traditionally (2019) the maximum number of events falls into two periods from March to June and from September to November. Due to the COVID-19 pandemic, the number of events in March-June of 2020 decreased significantly, and, starting from April, all of them were virtual. After the traditional vacation period in the EU countries in July-August, the number of events organized online began to grow gradually and by the end of 2020 reached the level of 2019.

Among all international events, it is worth noting brokerage activities, the main purpose of which is 


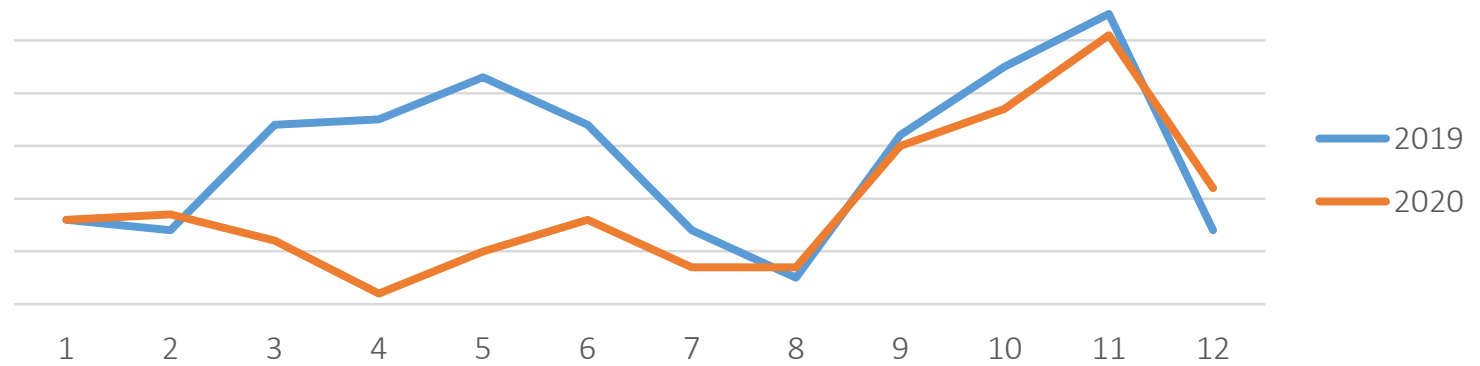

Figure 4. Distribution of the number of brokerage events by months in 2019 and 2020 according to the EEN event calendar

the organization of $\mathrm{B} 2 \mathrm{~B}$ meetings among the participants of the event to help them find potential partners abroad and to conclude specific, medium, or long-term cooperation agreements with the found partners. Analysis of the topics and directions of such events, the number of participants, and the number of meetings largely reflects the main trends in the development of modern international business.

Figure 4 shows the data of the distribution of brokerage events by months in 2019 and 2020 within the EEN event calendar.

It can be seen that the number of brokerage events in April 2020 decreased to a minimum, but since September has returned to the level of 2019. All these events became virtual from April 2020. Starting from July 2020, the number of participants in the brokerage events exceeded the figures of 2019 (Figure 6), and the number of the B2B meetings reached the level of 2019 (Figure 7). It should be noted that the organization and holding of large-scale international events appearing in the calendar of events on the EEN online platform have significantly contributed to the growth of participants in these events and the number of international online B2B meetings among them to establish cooperation in relevant areas. The attractiveness of such events is not only that they exacerbate the most pressing issues of globalization, but also allow affordable, time-optimized, mostly free participation of the most active professionals in their fields. The exchanges of views, ideas, and business proposals among representatives of various public organizations, small and medium-sized businesses, scientists, technologists, distributors, politicians, and government officials are much more active.

Thus, in November 2020 in Vienna (Austria), during the international forum "International Mobility Days 2020" a large-scale international brokerage event was held, which was attended by 1,261 representatives of various organizations, including leading universities from 68 countries and Ukraine. As a result of the event, more than 600 business meetings were held. The event was sup-

Source: Authors' elaboration.

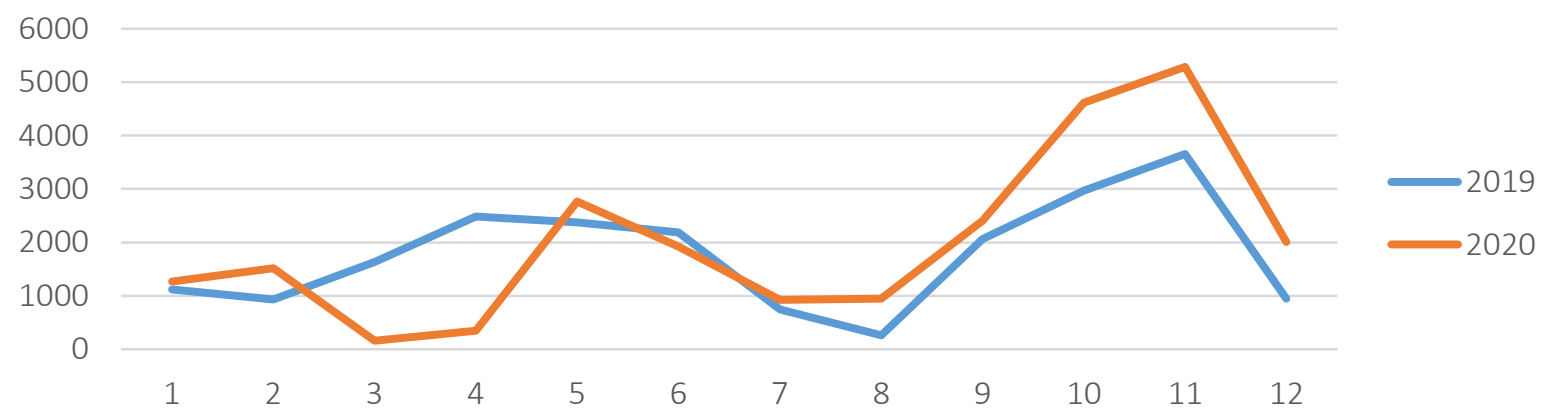

Figure 5. Monthly number of participants in brokerage events in 2019 and 2020 according to the EEN event calendar 
Source: Authors' elaboration.

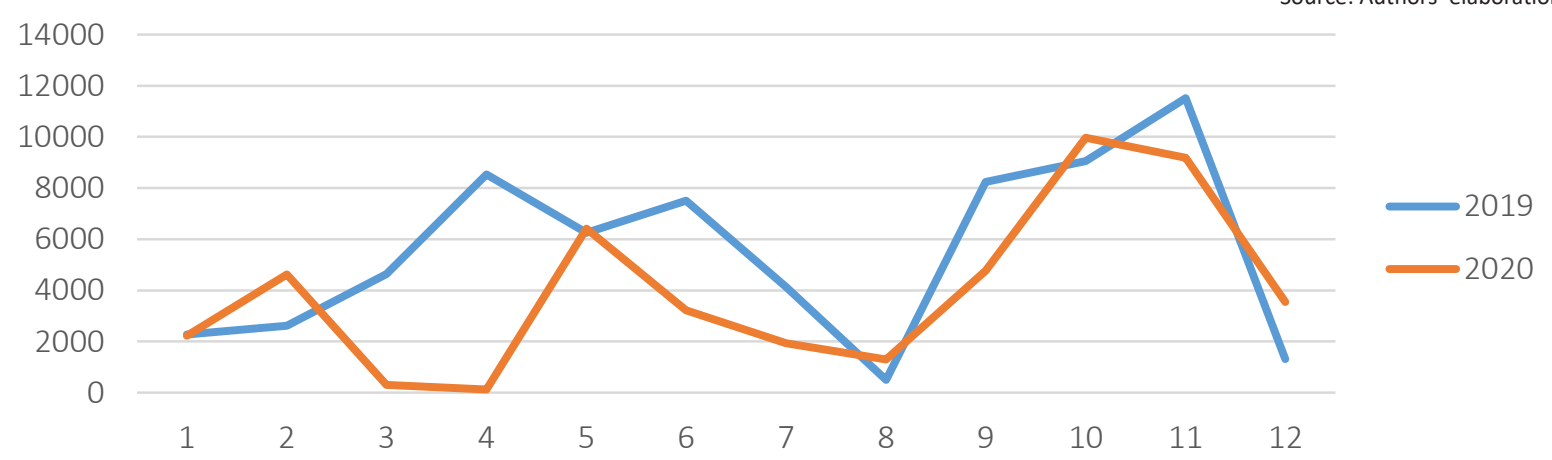

Figure 6. Monthly number of B2B meetings at brokerage events in 2019 and 2020 according to the EEN event calendar

ported by the Enterprise Europe Network in cooperation with AUSSENWIRTSCHAFT AUSTRIA, the Austrian Agency for Internationalization and Innovation of the Austrian Economy. The forum "International Mobility Days 2020" was organized free of charge on an online platform to develop urban mobility. The participants of the event had the opportunity to find potential partners for business cooperation, concluding license agreements for business development; establishment of joint ventures, startups; coordination of directions of joint research projects; sharing experiences and other partnership opportunities. 41 participants from Ukraine registered at the forum and held 18 international $\mathrm{B} 2 \mathrm{~B}$ meetings to establish new partnerships.

Active involvement of Ukrainian participants in the most relevant international events through the Enterprise Europe Network has added many impulses to establish new forms of interaction between Ukrainian entrepreneurs who produce or use innovative solutions in their work with other countries and regions of the world, which have offices of the Enterprise Europe Network.

Figures 7 and 8 show data, respectively, on the number of brokerage events in which Ukrainians took part in 2019 and 2020 and the number of participants from Ukraine in these events.

It can be seen that the transition to the online mode of brokerage events (from April 2020) allowed more participants from Ukraine to join the events (Figure 8). The number of the B2B meetings in which Ukrainians took part also increased significantly (Figure 9).

Figure 10 shows how the total number of Ukrainian participants in brokerage events increased in 2020 compared to 2019.

The most international brokerage events were held under the auspices of the EEN discussed various issues of development and competitiveness of innovative businesses based on the use of

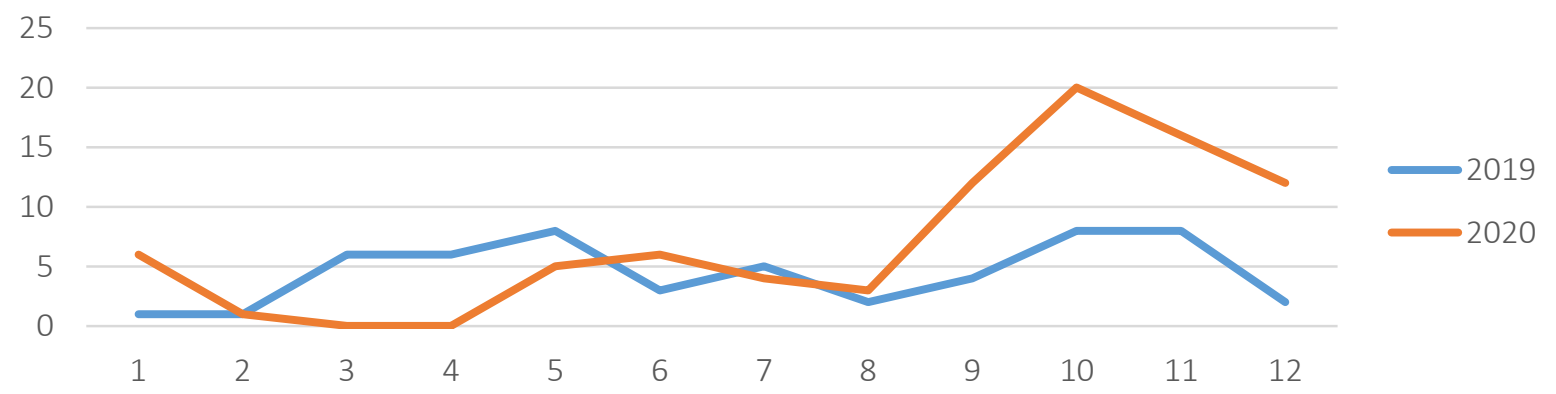

Figure 7. Monthly distribution of the number of brokerage events in which Ukrainian participants took part in 2019 and 2020 according to the EEN event calendar 


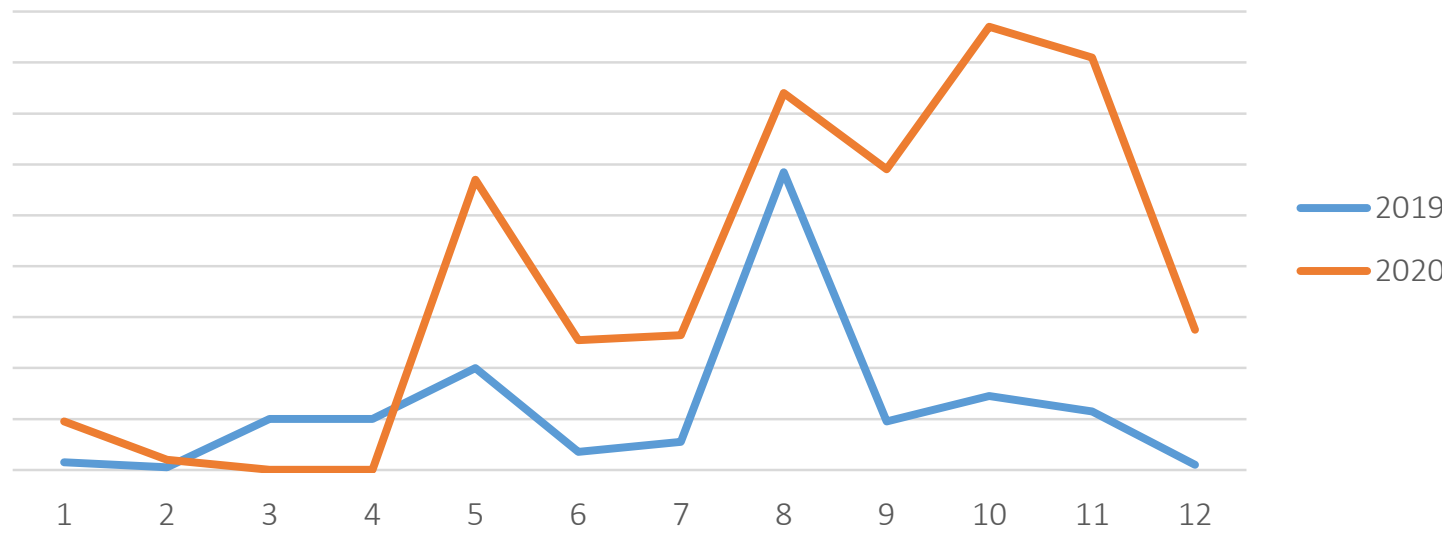

Figure 8. Monthly distribution of the number of Ukrainian participants in brokerage events in 2019 and 2020 according to the EEN event calendar

modern technologies that can significantly improve the level of technological development of firms, enterprises, organizations or universities and countries in general. The first place in terms of frequency of discussion was occupied by information and switching technologies, the main of them are Smart City, IoT, Artificial intelligence, Blockchain, Cybersecurity, Industry 4.0. The second place was taken by the Life science technologies in Healthcare and Bio-Chem-Tech areas. The third place was taken by technologies in the fields of Agrifood, Green energy, and Space Economy.

The results of hypothesis testing have proved that the changes that were not easy to predict not a long period are rapid to occur today. First, pushed by the spread of the pandemic of coronavirus the world economy has faced a crisis, which leads to inevitable and deep changes in the structure of the economy itself. The vivid appearance of such changes can be observed in all spheres and branch- es as well as in the everyday life of people changing the forms of communication and interactions among them. In such conditions, it is possible to speak about the coming of the sixth technological order instead of the fifth technological order. Altogether, $\mathrm{Hl}$ can be considered well grounded.

Second, the development of the digital economy changes the production relations among people towards their new peculiar distant forms. It can be even seen as the possibility of realizing the positive effects of digitalization because in terms of when the economy could have broken its development it moves to the new level of development thanks to the opportunities provided by the remote forms of economic interactions. That is why $\mathrm{H} 2$ can be considered proved.

Third, the pandemic stimulates the development of virtual forms of organizing the Enterprise Europe Network events that are important to stimulate

Source: Authors' elaboration.

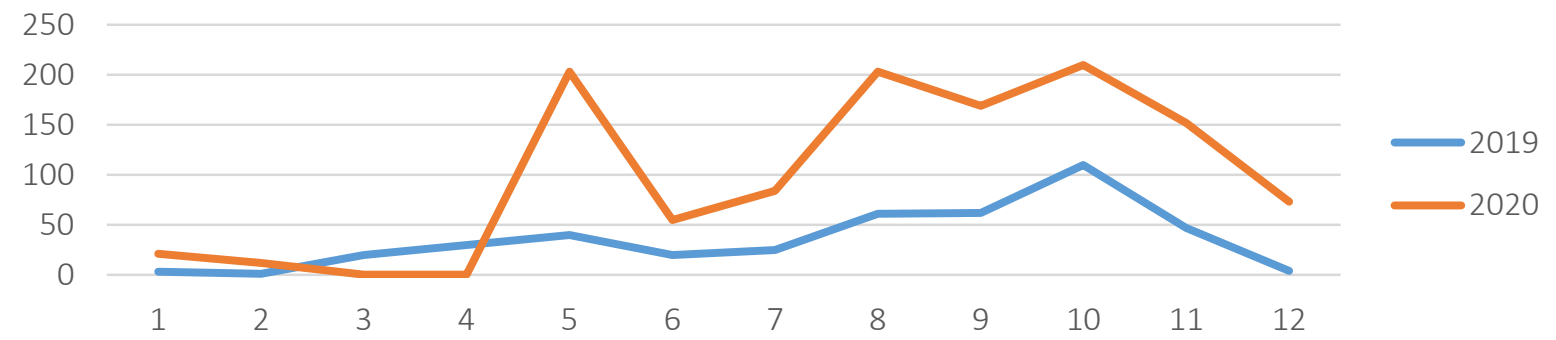

Figure 9. Monthly distribution of the number of the B2B meetings with Ukrainian participants in brokerage events in 2019 and 2020 


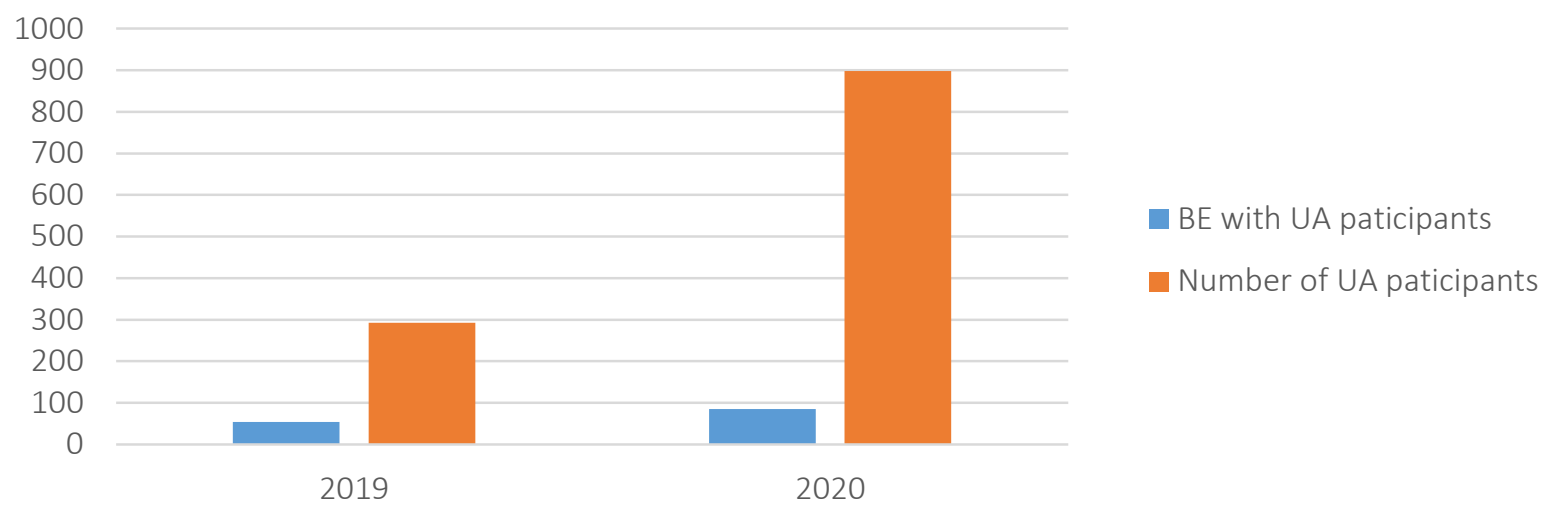

Figure 10. Comparative diagram of the total number of brokerage events in which Ukrainians took part and the number of participants from Ukraine in these events in 2019 and 2020

the development of small businesses, in particular concerning the technology transfer. It is quite understandable from the analytics presented above that before the pandemic the number of events, as well as event participants, was much lower. Concerning such countries as Ukraine, the low number of participants can be explained by the gap in the level of life of Ukrainians and the representatives of the European countries and the lack of possibility of the first ones to visit offline events. Thanks to the widespread of online events during the pandemic, the number of participants has grown significantly everywhere, in particular, the number of participants from Ukraine has grown. In the long run, all these result in strengthening the internationalization in business, science, and other spheres. It means that $H 3$ can be observed as substantiated.

\section{DISCUSSION}

It should be admitted that such crucial changes in the technologies used to happen before but they were mostly pushed by wars as accelerating factors of progress. In current conditions, the whole social and economic system of the world economy could be considered ready to the changes of technologies. The development of production relations and productive forces has reached a new level. The processes of digitalization of all branches and spheres of the world economy have been observed and fixed by scientists. The system of economic relations required the new forms of organization of business and work, i.e., distant forms became used and popular.

Simultaneously, economic crisis was anticipated by the analysts because of the end of economic cycles. However, without some pushing factors, such processes could not become dominating worldwide and the fifth technological order could not be driven out by the sixth technological order.

The pandemic spread has caused unprecedentedly tough quarantine measures and required quick changes in the organization of work and business towards distant ones. The new economy that is being formed will include virtual reality thanks to total digitalization whereas the material reality will be also changed significantly.

Will such profound changes in people's social and economic lives be painless? Will they be accompanied by a crisis and restructuring of existing forms of organization? Will certain branches of the economy, familiar to humankind, disappear forever, and will new branches based on nanotechnology and new medicine be created instead? In the end, will the establishment of the sixth technological order lead to positive consequences or, perhaps, will there be a return to the current technological level? 


\section{CONCLUSION}

The paper develops scientific research in the field of assessing the impact of the pandemic on the change of technological orders in current conditions and discusses the new forms of business running, in particular, in the internationalization of technology transfer. The paper aims to substantiate the technological orders' change caused by the pandemic and shows the process of digitalization as the new trend in the internationalization of technology transfer.

The findings prove that the deep and inevitable changes in the world economy can be observed. These changes in their essence can be determined as shifting to the next (the sixth) technological order instead of the fifth technological order that has been dominating until now. The technological order is a combination of technologies that have something in common and are connected to determine the social and economic development for some period. When a certain set of technologies exhaust itself and the productive forces together with production relations become ready for certain changes, the change of technological orders occurs bringing the whole system to a new level.

Due to the abovementioned changes, the processes of destroying and restructuring the elements of the old system can be observed. The coronavirus spread and the following tough quarantine limitations forced the search and implementation of the new forms of organization of work and business, in particular the distant ones. It has become possible thanks to the fact that the whole system of productive relations was ready to accept the changes. Digital technologies have made it partly possible to escape to distant forms of organization in the conditions of quarantine.

Some data showing the change of technological structures in the information and communication sphere demonstrate vividly the influence of the pandemics on events of the Enterprise Europe Network. After analyzing the calendar of events on the ENN platform, which reflects all significant international events for small and medium-sized businesses, an increase in activity in spring and autumn can be seen. It was during these periods that severe quarantine restrictions were imposed, which prompted businesses to move to an online space for further contacts in the B2B segment. The participation of Ukrainian businesses in establishing international contacts through this platform in the relevant segments is growing, which is facilitated by the simplified conditions for establishing the necessary contacts with international business representatives, namely the low cost of organizing online meetings. Such events are important to help small businesses to innovate and survive in modern conditions.

\section{AUTHOR CONTRIBUTIONS}

Conceptualization: Kateryna Alekseieva, Olga Kostyuk.

Data curation: Oleksandr Bediukh, Alla Stepanova.

Formal analysis: Kateryna Alekseieva, Olga Kostyuk.

Funding acquisition: Iryna Novikova, Oleksandr Bediukh, Alla Stepanova.

Investigation: Kateryna Alekseieva, Olga Kostyuk.

Methodology: Iryna Novikova.

Project administration: Iryna Novikova.

Resources: Iryna Novikova, Oleksandr Bediukh, Alla Stepanova.

Software: Oleksandr Bediukh, Olga Kostyuk.

Supervision: Kateryna Alekseieva, Iryna Novikova.

Validation: Kateryna Alekseieva, Olga Kostyuk.

Visualization: Iryna Novikova, Oleksandr Bediukh, Alla Stepanova.

Writing - original draft: Kateryna Alekseieva, Iryna Novikova.

Writing - review \& editing: Kateryna Alekseieva, Iryna Novikova, Alla Stepanova. 


\section{REFERENCES}

1. Agostini, L. Caviggioli, F., Galati, F., \& Bigliardi, B. (2020). A social perspective of knowledge-based innovation: mobility and agglomeration. Introduction to the special section. The Journal of Technology Transfer, 45(4), 13091323. https://doi.org/10.1007/ s10961-019-09766-5

2. Araújo, A. C., \& Teixeira, A. A. C. (2013). Determinants of international technology transfer: an empirical analysis of the Enterprise Europe Network (FEP Working Papers). Retrieved from http:// wps.fep.up.pt/wps/wp480.pdf

3. Bertosh, E. (2010). Mehanizm mezhdunarodnogo transfera tehnologij [The mechanism of international technology transfer]. Zhurnal mezhdunarodnogo prava i mezhdunarodnyh otnoshenij Journal of International Law and International Relations, 2, 79-83. (In Russian). Retrieved from http://evolutio.info/images/journal/2010_2/2010_2_bertosh.pdf

4. Block, F., \& Hirschhorn, L. (1979). New productive forces and the contradictions of contemporary capitalism. Theory and Society, 7, 363-395. https://doi.org/10.1007/ BF00207327

5. Bura, A., Humeniuk, B., \& Tanasienko, N. (2012). Problemy mizhnarodnoho transferu tekhnolohii v Ukraini [Problems of international technology transfer in Ukraine]. Visnyk Khmelnytskoho natsionalnoho universytetu - Bulletin of Khmelnytskyi National University, 2(1), 184-187. (In Ukrainian). Retrieved from http:// journals.khnu.km.ua/vestnik/pdf/ ekon/2012_2_1/184-187.pdf

6. Carayannis, E., Grigoroudis, E., \& Alexander, J. (2020). In pursuit of smart growth: technology transfer theories, policies and practices. The Journal of Technology Transfer, 45(6), 1607-1610. https://doi. org/10.1007/s10961-020-09779-5

7. Cyhn, J. W. (2002). Technology transfer and international production: the development of the electronic industry in Korea. Cheltenham, UK: Edward Elgar

\section{Publishing.}

8. De Moortel, K., \& Crispeels, T. (2018). International universityuniversity technology transfer: Strategic management framework. Technological Forecasting and Social Change, 135, 145-155. https://doi.org/10.1016/j.techfore.2018.05.002

9. Derakhshani, S. (1984). Factors affecting success in international transfers of technology. The Developing Economies, 21(1), 27-47. https://doi. org/10.1111/j.1746-1049.1984. tb00650.x

10. Enterprise Europe Network. (n.d.) Home. Retrieved from https://een. ec.europa.eu/

11. Fry, L. W. (1982). TechnologyStructure Research: Three Critical Issues. The Academy of Management Journal, 25(3), 532-52. https://doi.org/10.5465/256078

12. Jakubiak, M., \& Chrapowicki, P. (2017). Enterprise Europe Network as an Institution Supporting Smes' Internationalization - The Case Study. International Journal of Management and Applied Science (IJMAS), 3(11), 43-48. Retrieved from http://ijmas. iraj.in/paper_detail.php?paper_ $\mathrm{id}=10270 \&$ name $=$ Enterprise_Europe_Network_as_an_Institution_ Supporting_Smes\%27_Internationalization_-_The_Case_Study

13. Kotlyarevsky, Ya. V., Melnychenko, A. A., Ivanytska, O. M., Semenyuk, E. P., Kniaziev, S. I., \& Melnikov, O. V. (2020). New Economy: Evolution of Forms and Research Methodology. Science and Innovation, 16(1), 15-30. https://doi. org/10.15407/scine16.01.015

14. Kruger, S., \& Steyn, A. A. (2020). Enhancing technology transfer through entrepreneurial development: practices from innovation spaces. The Journal of Technology Transfer, 45(1), 1655-1689. https:// doi.org/10.1007/s10961-01909769-2

15. Lazebnyk, L. (2018). Didzhytalizatsiia ekonomichnykh vidnosyn yak faktor udoskonalennia biznes-protsesiv pidpryiemstv [Digitalizationof the economic relations as a factor in improving business processes of the enterprise]. Ekonomichnyi visnyk. Seriia: finansy, oblik, opodatkuvannia - Economic Bulletin. Series: Fanance, Accounting, Taxation, 2, 69-74. (In Ukrainian). https://doi.org/10.33244/26175932.2.2018.69-74

16. Lee, Y. N. (2020, March 11). 6 charts show the coronavirus impact on the global economy and markets so far. CNBC. Retrieved from https://www.cnbc. com/2020/03/12/coronavirusimpact-on-global-economy-financial-markets-in-6-charts.html

17. Melikyan, A. (2010). The Golden Billion. Retrieved from https:// www.yumpu.com/en/document/ $\mathrm{read} / 21064306 /$ the-goldenbillion-gab

18. Meshko, N. P., \& Robota, P. V. (2008). Komercializacija rezuljtativ naukovo-tekhnichnoji dijaljnosti u sferi mizhnarodnogho naukovo-tekhnichnogho obminu [Commercialization of the results of scientific and technical activities in the field of international scientific and technical exchange]. Ekonomichnyi prostir - Economic space, 12(1), 40-46. (In Ukrainian).

19. Negroponte, N. (1995). Being digital. Great Britain: Hodder and Stoughton. Retrieved from http:// governance40.com/wp-content/ uploads/2018/12/Nicholas-Negroponte-Being-Digital-Vintage-1996. pdf

20. Radu, S. (2018, November 7). Top Industries To Be Changed By Automation. U.S.news. Retrieved from https://www.usnews.com/news/ best-countries/slideshows/mostlikely-industries-to-be-changedby-automation

21. Rachinger, M., Rauter, R., Müller, C., Vorraber, W., \& Schirgi, E. (2019). Digitalization and its influence on business model innovation. Journal of Manufacturing Technology Management, 30(8), 1143-1160. https://doi. org/10.1108/JMTM-01-2018-0020 
22. Reddy, N., \& Zhao, L. (1990). International technology transfer: A review. Research Policy, 19(4). 285 307. https://doi.org/10.1016/00487333(90)90015-X

23. Smith, G. V., \& Parr, R. L. (2005). Intellectual Property. Valuation, Exploitation, and Infringement Damages ( $4^{\text {th }}$ ed.). John Wiley.

24. Stepanova, A., Bediukh, O., \& Novikova, I. (2019). Contradictions of Enterprise Europe Net- work Using in Ukraine. Problems and Perspectives in Management, 17(4), 190-202. http://dx.doi. org/10.21511/ppm.17(4).2019.16

25. Sykes, A. O. (2021). The Law and Economics of "Forced" Technology Transfer and Its Implications for Trade and Investment Policy (and the U.S.-China Trade War). Journal of Legal Analysis, 13(1), 127-171. https://doi.org/10.1093/ jla/laaa007
26. Taleb, N. (2008). The Black Swan: The Impact of the Highly Improbable. Penguin.

27. Yang, Y., McKhann, A., Chen, S . Harling, G., \& Onnela, J.-P. (2019). Efficient vaccination strategies for epidemic control using network information. Epidemics, 27, 115122. https://doi.org/10.1016/j. epidem.2019.03.002 